\title{
Editorial
}

\section{AIDS and the safety and adequacy of the Canadian blood supply}

It is now just over three years since it became apparent that blood and blood product therapy carried with them the risk of infecting recipients with the then unknown causative agent of acquired immunodeficiency syndrome (AIDS).

It was not long before the general public became aware of the risk of this possible means of transmission of the disease. Apprehension grew with the realization that effective action to ensure the safety of the blood supply from this threat was seriously limited by the fact that the causative agent was as yet unknown.

By early 1983, these circumstances made it necessary in countries where the incidence of AIDS was recognized as epidemic to adopt empirical, epidemiologically-based donor screening measures in order to minimize the risk of receiving unsafe blood. The new and different approaches implemented as a result of this initiative included education of donors as to the various high-risk factors associated with development and/or transmission of AIDS. Those with these high-risk factors were informed of their obligation to exclude themselves from donating blood. These measures became operative in both the United States and Canada by March 1983.

Given the psychological and sociological implications of such measures, it is to the credit of both the donors concerned and the blood collection and

From The Canadian Red Cross Soçiety Blood Transfusion Service, 95 Wellesley Street East, Toronto, Ontario, M4Y IH6. processing agencies that to date the supply of blood and blood products has, despite periods of serious depletion, remained adequate to meet therapeutic demands.

These measures have been acknowledged retrospectively to be sufficiently effective that they are listed as a primary precaution in the international guidelines for AIDS screening adopted in October 1985 by the International Society of Blood Transfusionists (ISBT). ${ }^{1}$ The indirectness of the measures, however, did little to allay the fears of either those requiring regular and continuing treatment with blood and blood products, such as haemophiliacs, or the general public, for whom haemotherapy was only a hypothetical consideration.

The encouraging discoveries of French and U.S. scientists later in 1983 and early in 1984 culminated in the recognition of a retrovirus as the causative agent of AIDS. The identification of what is now referred to as the human T-lymphotrophic virus III or lymphadenopathy-associated virus (HTLV-IIV LAV) made it possible to take a more direct approach to ensuring the safety of at least some blood products when it was learned, in May 1984, that the organism was particularly sensitive to heat inactivation at relatively low temperatures. ${ }^{2}$

Within months of the announcement of this possible means of improving the safety of some forms of haemotherapy, plasma fractionators had developed procedures that effectively inactivate the virus without adversely affecting the properties, potency and yield of plasma proteins, such as coagulation factors and albumin. By December 1984 , it was possible to assure Canadian haemophilia patients that, within six months - the estimat- 
ed time required for processing of Canadian plasma and its delivery to the Canadian Red Cross - all coagulation products provided by the Society would be heat-treated and the threat that their use might be a source of AIDS infection obviated.

Nevertheless, in the absence of a test that could be applied to donations on a routine basis to ensure that no blood or blood product capable of transmitting AIDS would be transfused, general confidence in the safety of the blood supply remained uncertain.

This deficiency was overcome considerably sooner than expected, since scientists at the U.S. National Institutes of Health were able to apply their special cell culture skills to the rapid production of HTLV-III/LAV in quantities suitable for the large scale manufacture of an enzyme-linked immunosorbent assay (ELISA test). This test screens for the presence of antibodies to the virus and was found to have measurability and time characteristics that made it suitable for adaptation to the requirements of a routine blood screening programme.

By early 1985 , test kits produced by five different manufacturers were ready for pre-licensing evaluation by several of the major North American blood collection agencies, including the Canadian Red Cross. By March of that year, the first licensed test was implemented by the American Red Cross (ARC) as part of its routine blood screening programme.

The criterion for discarding blood as unsafe for transfusion is that it be repeatably reactive* by the ELISA HTLV-III/LAV antibody procedure. This is considered to eliminate at least 95 per cent of potentially infectious bloods. The effect of this programme to further ensure the safety of the blood supply from transmission of the AIDS virus can best be judged by the figures currently available from the American Red Cross. With three million blood donations tested, the ARC has found it necessary to discard slightly under 0.4 per cent of blood donations; that is, 12,000 units (unpublished data).

Confirmatory testing of the repeatably reactive bloods by a more specific but much more timeconsuming antibody screening procedure, termed "the Western Blot," indicated that approximately

*Minimum of two positive ELISA tests.
1,200 of the 12,000 units were definitively positive for the antibody. This would indicate that approximately one in every 2,500 American Red Cross blood donors was found to be confirmed positive for the antibody (unpublished data).

Given that the sensitivity of the ELISA test is approximately 95 per cent, it can be calculated that the chances now of a unit of blood positive for the antibody to the AIDS virus being transfused in the United States are roughly one in 250,000 .

Much has been made of the fact that it was not until some six months after the American Red Cross initiated its anti-HTLV-III/LAV blood screening programme that a similar programme became operational in the Canadian Red Cross Blood Transfusion Service. While it is not the purpose of this editorial to attempt to justify any delay in the implementation of the screening in Canada, it is worthy of note that the commencement of testing by the American Red Cross was by no means indicative that such testing was undertaken simultaneously nationwide in the U.S. In fact, it was close to six months before comprehensive implementation could be achieved.

Complicated funding considerations, such as the profound differences in the way the Canadian and U.S. health care systems are financed, account in part for the difference in the implementation dates in the two countries. In the U.S., the rather substantial additional costs of testing could simply be added to the cost of a unit of blood to the user; whereas in Canada, provincial health ministries had to re-apportion funds budgeted for other purposes to cover those costs.

In addition, it was necessary to obtain a commitment from the provinces that they would make available, simultaneously with the implementation of the Red Cross testing programme, alternative testing facilities. This was considered to be essential in order to avoid the possible use of blood donation as a means of determining AIDS antibody status, thereby increasing the risk of contamination of the blood supply.

The Canadian Red Cross blood donation screening programme for the antibody to HTLV-III/LAV was actually initiated in October 1985, slightly over two months after full funding and commitment to the establishment of alternate testing facilities were announced. By the first week of November 1985 
all fresh blood components being distributed nationally had been screened for presence of the antibody.

Canadian Red Cross figures for the first two months of the screening programme indicate that the number of repeatably ELISA reactive units of blood discarded and the incidence of confirmed HTLV-III/LAV antibody positive donors are slightly lower, but essentially similar to those reported by the American Red Cross; that is, 0.25 per cent and 0.025 per cent respectively.

Given the current state of knowledge concerning just what the presence of antibody signifies about infectivity, it is difficult to project fully the extent of the risk in Canada of developing AIDS as an outcome of receiving blood or blood product therapy. Additional related imponderables at this time include the viral dosage factor, host susceptibility and presence of virus without detectable antibodies.

What can be said with a good deal of confidence, however, is that currently in Canada essentially all that can be done to ensure the safety of blood and blood products with respect to the transmission of AIDS is being done. There have been 14 reported cases attributed to receipt of blood or blood products since $1981,{ }^{3}$ all relevant haemotherapy having been given prior to the introduction of laboratory testing. Presumably, these would have been reduced by 95 per cent had the test been available throughout that period. Since there has been no dramatic increase in the number of cases of AIDS reported among Canadian recipients, it would be reasonable to conclude that the risk of developing AIDS from these sources has now been reduced to minuscule proportions.

What the influence of the introduction of antiHTLV-IILLAV blood donation screening will be on the adequacy of the Canadian blood supply remains to be seen. The test has great merit when used for the purpose for which it was developed, viz. blood donation screening. Unfortunately, in Canada, as indeed in almost all countries where the test is being carried out, there is a strong possibility of misinterpretation of a positive test result as indicative not only of AIDS, but also of promiscuity, homosexual activity and various other more or less socially unacceptable types of behaviour.

Thus, the assurance of confidentiality of test results is a matter of extreme importance when informing blood donors that their donation - and by inference, they - will be tested. The requirement in some provinces that the Red Cross report to public health authorities the identity of individuals whose blood tests positive for the antibody may well further discourage donors who are chafing already under the incursions that AIDS has made on their altruistic act of giving blood.

It is to be hoped that this will not lead to loss of donors with resultant inadequate blood supplies for therapeutic requirements. It could be avoided by a more flexible attitude on the part of public health authorities until the necessity for such reporting can be based on firmer evidence of the need for follow-up of antibody positive individuals beyond that which can currently be accomplished by education and through counselling by family physicians.

\section{Acknowledgement}

The author sincerely appreciates the assistance of Sadanand Mankikar and Kenneth Mews in the preparation of this manuscript.

\section{Le SIDA et la sûreté des approvisionne- ments en sang au Canada}

Il y a maintenant un peu plus de trois ans qu'on s'est rendu compte que l'utilisation du sang et des produits sanguins à des fins thérapeutiques comportait, pour le receveur, un risque d'infection par l'agent responsable (mais à l'époque non identifié) du syndrome d'immunodéficience acquise (SIDA).

Rapidement, le grand public est devenu conscient des risques de transmission de la maladie par le moyen de la transfusion, et son inquiétude s'est accrue au fur et à mesure qu'il a constaté que la 
sécurité des approvisionnements en sang était compromise du fait que l'agent causal de l'affection était inconnu.

Au début de 1983, cet état de choses a forcé les pays où le SIDA prenait des proportions épidémiques à adopter des mesures empiriques pour le dépistage épidémiologique des donneurs potentiellement dangereux. Parmi les mesures adoptêes, mentionnons l'information aux donneurs sur les facteurs les plus propres à favoriser le développement ou la transmission du SIDA et l'invitation lancée aux personnes les plus susceptibles d'être porteuses de l'agent causal à s'abstenir de donner du sang. Ces mesures étaient en vigueur aux ÉtatsUnis et au Canada dès mars 1983.

Étant donné la portée psychologique et sociologique de ces mesures, on ne peut que louer les donneurs et les organismes de collecte d'avoir maintenu, en dépit de périodes de pénurie sérieuse, les approvisionnements à un niveau suffisant pour répondre aux besoins des utilisateurs.

En rétrospective, on peut dire que ces mesures ont été si efficaces qu'elles sont devenues partie intégrante des règles préconisées en octobre 1985 par la Société internationale de transfusion sanguine en ce qui a trait au dépistage du SIDA. ${ }^{1}$ Mais, étant indirectes, ces mesures n'ont pas suffi à calmer l'inquiétude des utilisateurs habituels du sang et des produits sanguins, comme les hémophiles, ou du grand public, pour qui la thérapeutique transfusionnelle n'a qu'une signification hypothétique.

Fin 83 et début 84 , les travaux de chercheurs français et états-uniens aboutissaient à la mise en évidence d'un rétrovirus comme agent du SIDA. L'identification du microorganisme qu'on appelle aujourd'hui HTLV-III/LAV ("human T-lymphotropic virus" ou "lymphadenopathy-associated virus") et la découverte, en mai 1984, que ce virus pouvait être inactivé à des températures relativement peu élevées ${ }^{2}$ ont permis d'accroître la sécurité d'au moins quelques-uns des produits sanguins.

Quelques mois plus tard, les usines de fractionnement avaient mis au point des techniques efficaces d'inactivation du virus qui n'affectent en rien la quantité des protéines plasmatiques obtenues (en particulier l'albumine et les facteurs de la coagulation), ni leur propriétés. En décembre 84 , on pouvait assurer les hémophiles du Canada que, dans un délai de six mois (le temps nécessaire pour que le plasma prélevé au Canada soit livré à la CroixRouge canadienne pour distribution), les produits de fractionnement du plasma fournis par la Société seraient tous traités par la chaleur et rendus inoffensifs pour ce qui est de l'HTLV-III/LAV.

Toutefois, en l'absence d'un contrôle systématique des dons de sang pour éviter la transmission du virus par voie transfusionnelle, le grand public restait sceptique.

Cette carence a été comblée beaucoup plus tôt que prévu du fait que certains scientifiques des National Institutes of Health des États-Unis, mettant à contribution leur expérience de la culture des cellules, ont réussi à produire de l'HTLV-IIU/LAV en quantités suffisantes pour la commercialisation d'un ELISA ("enzyme-linked immunosorbent assay") de détection des anticorps anti-HTLV-IIl/ LAV. On s'est vite rendu compte que cette épreuve pouvait donner des résultats mesurables, et ce dans un délai suffisant pour qu'on l'adopte aux fins du dépistage systématique dans les dons de sang.

Au début de 1985, les organismes nordaméricains de collecte de sang, dont la Croix-Rouge canadienne, ont fait l'étude des trousses mises sur le marché par cinq fabricans différents dans le but de savoir si ces trousses pouvaient recevoir l'aval des autorités santitaires. Dès le mois de mars 85 , la Croix-Rouge américaine adoptait le premier test officiellement accepté et l'introduisait dans sa batterie d'épreuves pratiquées systématiquement sur tous les dons de sang.

C'est une réaction positive répétée* lors de l'ELISA des anti-HTLV-IIU/LAV qui constitue le critère du rejet d'un don de sang. On estime qu'avec ce test, on peut éliminer au moins 95 pour cent des sangs potentiellement infectants. On peut se rendre compte de l'effet de cette mesure sur la sécurité du sang ou des produits sanguins en consultant les dernières statistiques de la Croix-Rouge américaine, qui a trouvé, sur trois millions de dons de sang, 12000 sacs réagissant positivement lors du test, soit 0,4 pour cent (données non encore publiées).

De ce nombre, environ 1200 sacs ont réagi positivement à une épreuve de contrôle ("Western Blot") plus spécifique mais aussi beaucoup plus

${ }^{*}$ Minimum de deux ELISA positifs. 
longue d'exécution. Ce qui veut dire que, dans le cas de la Croix-Rouge américaine, environ 1 donneur sur 2500 a réagi positivement aux deux types de tests de dépistage des anticorps antiHTLV-IIULAV (données non encore publiées).

Comme on estime à 95 pour cent la sensibilité de I'ELISA, on peut dire qu'aux États-Unis, le risque de transfusion d'un sac de sang réagissant positivement ou des produits provenant de ce sac est, grosso modo, de $1 / 250000$.

On a beaucoup fait état du prétendu délai dont se serait rendu responsable le Service de transfusion de la Croix-Rouge canadienne dans la mise en application du dépistage systématique des anticorps antiHTLV-IIL/LAV, étant donné que la Croix-Rouge américaine a commencé à exécuter le test six mois avant nous. Bien que cet éditorial n'ait pas pour but de justifier ce délai, il importe de souligner qu'à la date où la Croix-Rouge américaine a commencé à utiliser le test, celui-ci était loin d'être utilisé sur l'ensemble du territoire américain et que son emploi n'est devenu généralisé qu'au bout de six mois.

Des facteurs financiers complexes, fondés sur les différences de structure des soins médicaux de part et d'autre de la frontière, expliquent en grande partie le temps qui s'est écoulé entre la mise en application du test aux États-Unis et au Canada. Aux États-Unis, on ajoute tout simplement le coût relativement élevé du test au prix que doit payer le receveur, alors qu'au Canada, les autorités compétentes ont dû, pour financer l'opération, redistribuer des crédits déjà affectés à des postes budgétaires donnés.

En outre, avant la mise en place du programme de dépistage, les autorités sanitaires des provinces ont du s'engager à rendre accessible le test aux médecins en dehors de la Croix-Rouge, car, autrement, le don du sang aurait pu devenir pour ceux-ci un moyen de connaître la présence des anticorps anti-HTLV-IIL/LAV chez certains sujets, ce qui aurait augmenté le degré de contamination de nos approvisionnements en sang.

C'est en octobre 85 que la Croix-Rouge canadienne a mis en vigueur le dépistage systématique des anticorps anti-HTLV-III/LAV, soit un peu plus de deux mois après que les provinces eurent accepté de le financer et aussi d'offrir aux médecins la possibilité de faire le test dans certains laboratoires quand il s'agissait de malades. Dès la première semaine de novembre 85 , toutes les fractions sanguines fraîches distribuées par le Service de transfusion avaient été soumises au dépistage des anticorps anti-HTLV-IIU/LAV.

Les chiffres de la Croix-Rouge canadienne pour les deux premiers mois révèlent que le nombre de sacs trouvés positifs par l'ELISA à deux reprises et donc détruits, ainsi que le nombre de donneurs reconnus porteurs d'anti-HTLV-IIU/LAV sont légèrement inférieurs mais du même ordre qu'aux États-Unis, soit 0,25 pour cent et 0,025 pour cent respectivement.

Étant donné l'état actuel de nos connaissances sur le pouvoir infectant des sujets porteurs d'anticorps anti-HTLV-III/LAV, il est difficile de prévoir exactement dans quelle mesure un receveur risque de présenter une infection à HTLV-III/LAV à la suite d'une transfusion de sang ou de produit de fractionnement. Parmi les impondérables qui persistent, il faut mentionner l'effet-dose du virus, la sensibilité des hôtes et la présence du virus sans anticorps concomitants décelables.

Ce qu'on peut dire avec assurance, c'est qu'au Canada, en ce moment, tout ce qui doit être fait pour que le sang et les produits du sang soient sécuritaires en ce qui a trait à l'HTLV-IIJ/LAV est fait. Depuis 1981 , on a rapporté 14 cas d'infection à HTLV-III/ LAV attribuables à la transfusion de sang ou de dérivés du sang. ${ }^{3}$ Or tous ces cas découlaient de transfusions données avant l'entrée en vigueur du programme de dépistage. Le test de dépistage aurait sans doute réduit ce nombre de 95 pour cent. En l'absence d'une augmentation notable des cas d'infections à HTLV-III/LAV parmi les receveurs au Canada, il serait raisonnable de conclure que le risque de faire l'infection à cause d'une transfusion est maintenant très faible.

Reste à savoir de quelle manière le dépistage des anti-HTLV-IIJ/LAV influencera le don du sang. La raison d'être du test est avant tout le dépistage des donneurs potentiellement infectants. Malheureusement, ici comme dans la plupart des pays où on le pratique, il y a de grosses chances que la population interprète les résultats comme s'ils constituaient une preuve d'infection avérée, de promiscuité, d'activités homosexuelles ou d'autres comportements plus ou moins condamnés par la société.

C'est pourquoi il est extrêmement important de respecter le caractère confidentiel des résultats au 
moment d'informer le donneur que son sang (ou lui-même par voie de conséquence) doit être soumis à des épreuves de confirmation. Le fait que certaines provinces exigent de la Croix-Rouge qu'elle révèle aux autorités sanitaires l'identité des sujets ayant réagi positivement au test de dépistage pourrait bien décourager davantage les donneurs qui hésitent déjà à donner leur sang à cause de l'ombre que le SIDA a jeté sur leur altruisme.

Il faut espérer de toute façon que cet état de choses ne réduira pas le nombre de nos donneurs et, partant, l'importance de nos approvisionnements. Une telle éventualité pourrait être évitée si les autorités sanitaires se montraient plus flexibles, en tout cas tant que la nécessité d'une telle déclaration ne sera pas fondé sur des arguments formels indiquant qu'il est nécessaire de faire plus, dans le cas des sujets porteurs d'anticorps, que de leur enseigner les règles d'hygiène qui les concernent. Or ceci a le plus de chances d'être fait correctement par le médecin de famille.

\section{Remerciements}

L'autreur désire remercier MM. Sadanand Mankikar et Kenneth Mews pour l'aide qu'ils ont apportée à la préparation du manuscrit.

\section{References}

1 International Society of Blood Transfusionists Newsletter, January 1986.

2 Spire B, Dormont D, Barré-Sinousssi F, Montagnier $L$, Chermann JC. Inactivation of lymphadenopathyassociated virus by heat, gamma rays, and ultraviolet light. Lancet 1985; 1 : 188.

3 Update: "AIDS" in Canada. The Laboratory Centre for Disease Control, Ottawa. January 20, 1986. 